\title{
Problems in differential diagnosis of diabetes types*
}

\author{
Maciej Małecki, Jan Skupień \\ Department of Metabolic Diseases, Collegium Medicum Jagiellonian University, Kraków, Poland
}

\begin{abstract}
Diabetes mellitus is a group of diseases characterized by chronic increase of glucose level. The last years brought progress in understanding the multiplicity of its forms, as well as, its complex pathogenesis. In 1999, a classification of diabetes based on the etiology of individual types, was proposed by the Experts Committee of the World Health Organization, and is now commonly accepted. Etiologic classification in the last decade was gradually extended with the progress of knowledge, in particular, with successes of researchers in the field of genetics. Monogenic forms of diabetes such as MODY, mitochondrial diabetes, neonatal diabetes and lipoatrophic diabetes, discovered over a dozen years ago, are characterized by unique clinical features and possibility of applying a tailored treatment, assuring optimal correction of genetically conditioned metabolic defect. The differential diagnostics of types of the diseases is playing an increasing role in diabetology, as it enables selection of optimal treatment methods, as well as, the assessment of prognosis referring to the diabetes course and complications occurence. In this article, a review of problems associated with the differential diagnostics of diabetes and its practical clinical application was made.
\end{abstract}

Key words: diabetes mellitus, differential diagnosis, genes

* This article is based on the lecture which was presented at the 36th Congress of the Polish Society of Internal Medicine, Warsaw, Poland, April 26, 2008

\section{INTRODUCTION}

Diabetes melitus is a common name for a group of diseases of a very diversified etiopathogenesis, characterized by chronically increased concentration of blood glucose. Investigators have been aware of existence of different forms of diabetes for a long time, however, only the last decade brought a substantial progress in identification and understanding of etiology of its distinct types. The present classification of diabetes, published by WHO in 1999, is based on the etiology of its individual forms [1]. Progress of knowledge concerning the pathogenesis of different types of diabetes often finds a spectacular application in the clinical practice, enabling the employment of individually selected, effective treatment, determining the prognosis and risk of complications.

The most frequent form of disease is type 2 diabetes mellitus, formerly referred to as noninsulin dependent diabetes mellitus (NIDDM). It develops as a result of interactions of genetic and environmental risk factors, which lead to relative deficiency of insulin with coexisting resistance to its activity [2]. It is typically observed in adulthood, often in elderly and characterized by a possibility, in many instances, to con-

Correspondence to:

Maciej T. Małecki MD, PhD, Katedra i Klinika Chorób Metabolicznych, Collegium Medicum UJ, ul. Kopernika 15, 31-501 Kraków, Poland, phone: +48-12-424-83-05, e-mail: mmalecki@cm-uj.krakow.pl,malecki_malecki@yahoo.com

Received: March 10, 2008. Accepted: April 24, 2008.

Conflict of interest: none declared.

Pol Arch Med Wewn. 2008; 118 (7-8): 435-440

Translated by Grażyna Golańska, MA

Copyright by Medycyna Praktyczna, Kraków 2008 trol glycemia with diet or diet combined with oral hipoglycemic drugs, without need ofo insulin therapy, at least at the beginning of the disease. Obesity, hypertension and lipid abnormalities usually accompany type 2 diabetes. The is difficult to identify, asymptomatic or oligosymptomatic. The family history for diabetes is often positive.

The second most frequent form of the disease is type $1 \mathrm{di}$ abetes [3]. It is characterized by absolute insulin deficiency. The diagnosis is most often accompanied by acute symptoms resulting from dehydration and accompanying ketoacidosis, sometimes with dramatic course. Type 1 diabetes definitely requires insulin treatment. The cause of the disease is the autoimmune process directed against pancreatic $\beta$ cells. The diabetes afflicts almost frequently young people, in the first, second and third decade of life. The occurrence of elements of the metabolic syndrome does not fit the standard image of type 1 diabetes, however, it can sometimes accompany the disease.

Differentiation of type 1 and type 2 diabetes is not a difficult task when the image of the disease does not diverge from the above description. Nevertheless, in clinical practice, we can face difficulties resulting from the fact that not all patients present typical features of the most frequent forms, mainly with reference to clinical symptoms, body weight or age recognition.

\section{Diabetes type 2 in children and adolescents, and latent autoimmune diabetes of adults (LADA)}

The lowering age of diagnosing type 2 diabetes, particularly in developed countries, is a growing and worrying phenom- 


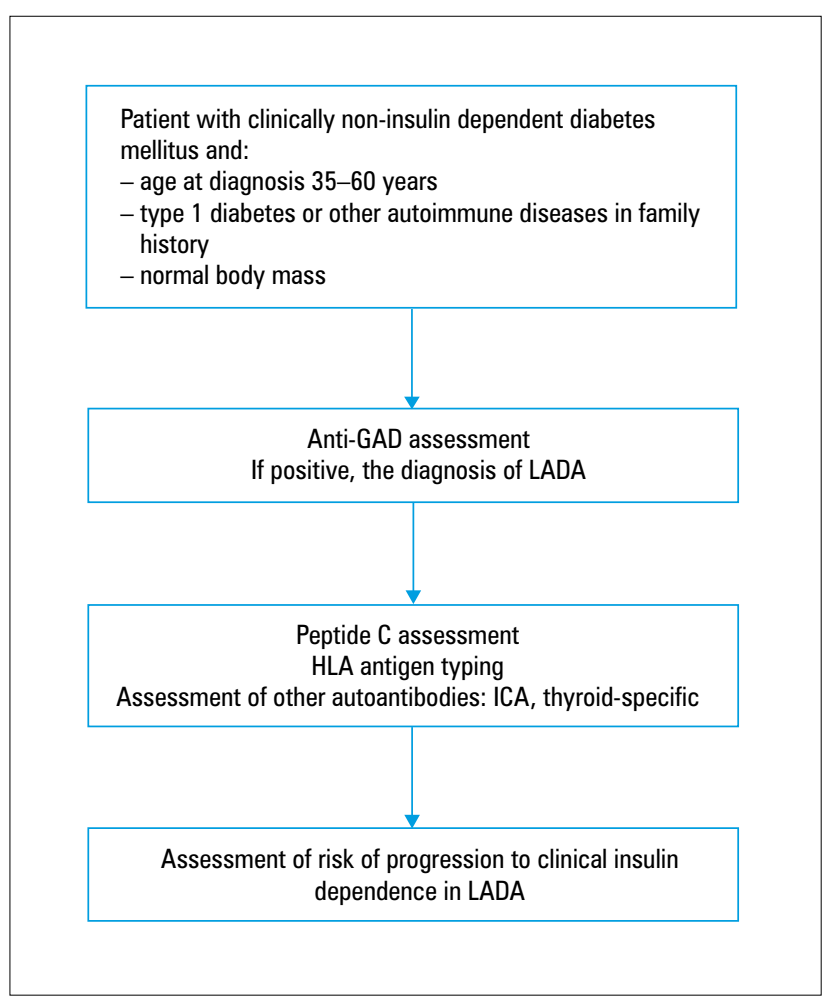

Fig. Proposed diagnostic algorithm in latent autoimmune diabetes of adults (LADA), according to reference [9]. Abbreviations: GAD glutamic acid decarboxylase, HLA - human lymphocyte antigens, ICA - islet cell antibodies

enon [4]. This disease more and more often affects pediatric populations. The main role is being assigned to environmental factors: high caloric diet and low physical activity. Children, adolescents and young adults with type 2 diabetes present the characteristic clinical picture, which comprise the elements of the metabolic syndrome. The parents of these patients are often affected with type 2 diabetes. In biochemical tests, a high C-peptide is typical and markers of autoimmunity are negative.

Type 1 diabetes can develop in persons in the fourth decade of life or later without any characteristic acute symptoms [5]. The most popular acronym describing this form of diabetes (not included as a separate entity in the WHO classification) is LADA - latent autoimmune diabetes of adults [6]. When type 1 diabetes develops with acute symptoms in a person over 30 years old, then the appropriate diagnosis is most often not difficult [7]. However, LADA diabetes develops secretly, under the mask of insulin independency. Differentiating type 2 diabetes and LADA has important clinical meaning. It is caused by the fact that animal models suggest a protective action of exogenously administered insulin in sustaining function of the $\beta$ cells in the presence of the autoimmune process. The phenomenon of this protective action of insulin is explained by immunomodulating action of the hormone [8] or by reducing exhaustion of the damaged cells as a re- sult of the exogenous insulin supplementation $[9,10]$. Nevertheless, the direct evidence for the beneficial action of early insulin therapy in type 1 diabetes in humans turned out to be difficult. Using insulin in healthy persons with genetic predisposition to type 1 diabetes and the presence of autoantibodies against the $\beta$ cells did not show any benefit from such intervention [11]. However, a study in Japanese population showed a protective insulin activity in LADA diabetes [12]. Certain indirect evidence for beneficial influence of insulin on preserving activity of insulin secreting cells, measured with C-peptide level, was revealed by the DCCT trial (Diabetes Control and Complications Trial), showing association with treatment regimen [13]. Since preserving the residual pancreatic endocrine function, i.e. secreting insulin, is an important aspect of therapy of type 1 diabetes, an early identification of patients with LADA in order to apply insulin treatment, has a serious clinical importance. The lack of metabolic syndrome features or type 2 diabetes in family and the presence of different diseases from the autoimmunity, both in the patient and his relatives, might be helpful in differential diagnosis in respect to type 2 diabetes. The $\mathrm{C}$-peptide level can be decreased or within the normal range. Assessment of anti-GAD antibodies (glutamic acid decarboxylase - GAD) is a deciding test. It is worth to emphasize its high diagnostic sensitivity, long lasting increased titre and relatively simple methodology of detection [14-16]. The islet cell antibodies (ICA) are equally sensitive, however, soon after diagnosing diabetes, they are not detectable, moreover, they require a complicated detection assay [15]. Other autoimmune markers of $\beta$ cells are rarely used due to their lower sensitivity $[17,18]$. Because of similar clinical value of anti-GAD and ICA, their routine combined assessment is not necessary. Patients with LADA are characterized by much faster loss of the endocrine function of islets than patients with type 2 diabetes, therefore, an early ineffectiveness of treatment with oral drugs is an essential clinical symptom [19]. The Figure shows the suggested diagnostic procedure in LADA diabetes. The Tables 1 and 2 present clinical features of MODY, LADA and type 2 diabetes, useful in differential diagnostics.

\section{Other specific forms of diabetes}

The problems we can encounter in differentiating type 1 and 2 diabetes were presented above. WHO classification [1] includes, except these two, dozens of different forms of the disease. Numerous forms of secondary diabetes, evoked by medicines or hormonal disorders can clinically ressemble type 2 diabetes, rarely type 1 , for example diabetes of autoimmune basis, triggered by interferon administration [20]. The differential diagnostics of such secondary diabetes is based on the identification of factor being capable to trigger the disease. We deal with such a situation in case of pancreatic disorders or surgery on this organ, complicated by diabetes. Monogenic forms of diabetes, such as genetic defects of insulin secretion and, rarely appearing, genetic defects of the hormone action are of great clinical importance. The most fre- 


\begin{tabular}{cll}
\hline $\begin{array}{c}\text { Table 1. Comparison of selected clinical features helpful } \\
\text { in differential diagnosis of MODY and LADA }\end{array}$ & LADA \\
\hline & MODY & Rare \\
\hline $\begin{array}{c}\text { Multigeneration family } \\
\text { history }\end{array}$ & Frequent & Present \\
\hline $\begin{array}{c}\text { Anti-pancreatic } \\
\text { antibodies }\end{array}$ & Absent & Not detectable \\
\hline $\begin{array}{c}\text { C-peptide after several } \\
\text { years from diagnosis }\end{array}$ & Present & Not typical \\
\hline $\begin{array}{c}\text { Renal and genital tract } \\
\text { malformations }\end{array}$ & May occur & May occur \\
\hline $\begin{array}{c}\text { Accompanying } \\
\text { autoimmune diseases }\end{array}$ & Not typical & \\
\hline $\begin{array}{c}\text { HLA-DR3 and DR4 } \\
\text { haplotypes }\end{array}$ & $\begin{array}{c}\text { Several percent of } \\
\text { cases }\end{array}$ & In over half cases \\
\hline
\end{tabular}

quent form of genetic defect of $\beta$ cells is a group of disorders referred to with acronym MODY (maturity onset diabetes of the young) [21].

\section{MODY diabetes}

Currently, there are 6 MODY subtypes associated with gene mutations: hepatocyte nuclear factor (HNF)- $4 \alpha$ MODY1 [22], glucokinase (GCK) - MODY2 [23,24], HNF1 $\alpha$ - MODY3 $[25,26]$, insulin promoter factor (IPF)-1 - MODY4 [27], HNF1 $\beta$ - MODY5 [28], NEUROD1/ $\beta_{2}-$ MODY6 [29]. MODY is usually diagnosed in the second or third decade of life, the beginning of the disease is asymptomatic, usually there is no ketoacidosis. The diabetes do not require insulin treatment for many years after the diagnosis has been made and it is not accompanied by metabolic syndrome features such as obesity, lipid disorders or hypertension [21]. A positive family history is characteristic, typical for the dominant autosomal inheritance of a diseases with high phenotypic penetrance. The patients with MODY diabetes do not have elevated C-peptide level, they also do not reveal the presence of specific autoantibodies for $\beta$ cells. The definitive diagnosis can be made on the basis of genetic testing, as in case of other monogenic forms of diabetes. Certain MODY subtypes reveal some characteristic features, facilitating the preliminary diagnosis. A common MODY2 diabetes, which is the mildest form of the disease, is included here. The satisfying metabolic compensation is usually achieved by only diabetic diet. The risk of chronic complications is small [30]. The patients are characterized by increased fasting glucose levelshowever after a challenge test, the increase in the glucose concentration is relatively small and it is not exceeding $2-3 \mathrm{mmol} / \mathrm{l} \mathrm{com}-$ pared to the baseline [31]. The metabolic defect does not reveal a tendency to increase over time. The remaining MODY subtypes are associated with mutations of transcription factors. The most common of the forms is MODY3 linked to the mutations of the HNF1 $\alpha$ gene. The element facilitating

\begin{tabular}{lll}
\hline $\begin{array}{l}\text { Table 2. Comparison of selected clinical features helpful in } \\
\text { differential diagnosis of MODY and type 2 diabetes } \\
\text { mellitus }\end{array}$ & MODY & Type 2 diabetes \\
\hline Clinically insulin independent & Yes & Yes \\
\hline Parents with diabetes & 1 & $1-2$ \\
\hline Obesity & Not common & Common \\
\hline Autoantibodies & No & No \\
\hline Genetic testing & Helpful & Not useful \\
\hline
\end{tabular}

differential diagnosis is renal tubulopathy resulting in lowered renal threshold for glucose [32]. Plasma 1,5-anhydroglucitol, a monosaccharide which concentration depends on the renal threshold for the glucose, can be a useful biochemical marker [33]. Moreover, the MODY3 can rarely be accompanied by developmental renal defects in form of hypoplasia or agenesis [33], and adenomas of the liver [34]. Diagnosing MODY3 has a great clinical meaning as a treatment of choice in this disease are the derivatives of sulphonylurea [35]. The other, less common subtype, where clinically extrapancreatic symptoms facilitating differentiating diagnostics appear, is MODY5. Here, the developmental renal disorders often appear in the form of policystic degeneration and the impairments of filtration function [36].

\section{Mitochondrial diabetes}

This monogenic form of diabetes resulting from impairment of insulin secretion is associated with mutations of the mitochondrial genome [37]. As a result of such etiology, the disease reveals so-called maternal inheritance as it is passing in family from generation to generation, transmitted exclusively by women. It is accompanied by the characteristic extrapancreatic symptoms, the most often sensoric hypoacusis, hence the MIDD acronym (maternally inherited diabetes with deafness) [38]. Mutations responsible for MIDD, first of all and most frequent, in position 3243 of mitochondrial genome, are also linked with different syndrome - MELAS (mitochondrial myopathy, encephalopathy, lactic acidosis and strokelike episodes) [39]. Even though MIDD and MELAS constitute separate entities, their elements overlap in some instances. The clinical picture of diabetes is diversified from asymptomatic, slowly developing diabetes, to relatively fast progressing defect of $\beta$ cells requiring insulin therapy [40]. The diagnosis usually takes place between the second and the fifth decade of life. Metformin should be avoided in treatment, due to a potential risk of lactic acidosis. This rare form of diabetes should be expected in case of maternally inherited diabetes combined with deafness. The level of C-peptide is normal or decreased, the autoimmune markers are negative. In differential diagnostics, an audiogram and ophthalmological examination is sometimes helpful, because of a characteristic macu- 
lar pattern dystrophy [41]. The history of elements of MELAS syndrome, as well as family history might be helpful in differential diagnosis.

\section{Genetic forms of insulin resistance}

This is a diversified group of diabetes of different degree of severity. Lethal pediatric syndromes, such as leprechaunism [42] or Rabson-Mendenhall syndrome [43], associated with mutations of the insulin receptor, are included here. Other mutations are responsible for milder form, type A insulin resistance [44]. The range of different genes is associated with generalized or partial lipodystrophy (lamin gene mutations and PPAR- $\gamma$ receptor are associated with the latter $[45,46]$ ) According to the name, the syndromes are characterized by subcutaneous tissue atrophy and its altered distribution. The common features of diabetes with extreme insulin resistance are: hypertriglicerydemia, hypercholesterolemia, low level of HDL, hepatosplenomegaly, acanthosis nigricans, hiperandrogenism, hirsutism, virilisation and menstruation disorders [47]. Nevertheless, these are not the characteristic symptoms of monogenic defects of insulin action.

\section{Neonatal diabetes}

The most important diagnostic criterion of neonatal diabetes is disease onset in the first 6 months of life [48]. Neonatal diabetes can have a transient or permanent form, clinically resembling type 1 diabetes. About $50 \%$ of cases of the latter form are linked to mutations in genes of potassium channel subunits expressed in $\beta$ cells: Kir6.2 and SUR1 $[48,49]$. Some carriers of these genes mutation (about one third) reveal, apart from diabetes, neurological symptoms such as mental retardation, muscle weakness, epilepsy [48,49]. The derivatives of sulphonylurea, enable not only normoglycemia but also, to certain extent, decrease of neurologic disorders [50]. The treatment was effective in treatment of the majority of cases [51]. Referral of a patient with neonatal diabetes to a health centre, which has genetic testing facility, has a crucial meaning for later prognosis and life quality.

In summary, it should be emphasized that the appropriate differentiating of forms of diabetes has more and more clinical meaning. Most often, the appropriate diagnosis can be made, with great probability, on the basis of interview, physical examination and relatively simple biochemical or immunological tests. Currently, the genetic screening and counseling play an important role in clinical care of patients with monogenic forms of diabetes, and in a smaller degree in the complex forms of the disease. However, the prognostic value of such tests is very limited in type 1 diabetes and particularly type 2 diabetes. Hence, we draw a conclusion that molecular diagnostics of these complex, polygenic types of diabetes still do not have clinical application. Nevertheless, there is a hope that in the future with the improved understanding of a more complete image of the role of genetic factors and their inter- action with environment, prognostic, diagnostic and therapeutic role of genetic testing will considerably increase. This will create a field for diabetes specialists, clinical geneticists, molecular biologists and pharmacologists for a wide cooperation with a patient complex care which will allow individualization the therapy.

\section{REFERENCES}

1. World Health Organization: Definition, diagnosis and classification of diabetes mellitus and its complications. Report of a WHO Consultation. Geneva, 1999.

2. Malecki MT, Klupa T. Type 2 diabetes mellitus: from genes to disease. Pharmacol Rep. 2005; 57 (Suppl): 20-32.

3. Atkinson MA, Eisenbarth GS. Type 1 diabetes: new perspectives on disease pathogenesis and treatment. Lancet. 2001; 358: 221-229.

4. Pontiroli AE. Type 2 diabetes mellitus is becoming the most common type of diabetes in school children. Acta Diabetol. 2004; 41: 85-90.

5. Turner R, Stratton I, Horton V, et al. UKPDS 25: autoantibodies to islet-cell cytoplasm and glutamic acid decarboxylase for prediction of insulin requirement in type 2 diabetes. UK Prospective Diabetes Study Group. Lancet. 1997; 350: 1288-1293.

6. Pozzilli P, Di Mario U. Autoimmune diabetes not requiring insulin at diagnosis (latent autoimmune diabetes of the adult): definition, characterization, and potential prevention. Diab Care. 2001; 24: 1460-1467.

7. Lorenzen $T$, Pociot $F$, Hougaard $P$, et al. Long-term risk of IDDM in first-degree relatives of patients with IDDM. Diabetologia. 1994; 37: 321-327.

8. Atkinson MA, Maclaren NK, Luchetta R. Insulitis and diabetes in NOD mice reduced by prophylactic insulin therapy. Diabetes. 1990; 39: 933-937.

9. Bertrand S, De Paepe M, Vigeant C, et al. Prevention of adoptive transfer in BB rats by prophylactic insulin treatment. Diabetes. 1992; 41: 1273-1277.

10. Gottlieb PA, Handler ES, Appel MC, et al. Insulin treatment prevents diabetes mellitus but not thyroiditis in RT6-depleted diabetes resistant BB/Wor rats. Diabetologia. 1991, 34:296-300.

11. Diabetes Prevention Trial-Type 1 Diabetes Study Group: Effects of insulin in relatives of patients with type 1 diabetes mellitus. N Engl J Med. 2002; 346: 1685-1691.

12. Kobayashi T, Nakanishi K, Murase T, et al. Small doses of subcutaneous insulin as a strategy for preventing slowly progressive beta-cell failure in islet cell antibody-positive patients with clinical features of NIDDM. Diabetes. 1996; 45: 622-626.

13. The Diabetes Control and Complications Trial Research Group. Effect of intensive therapy on residual beta-cell function in patients with type 1 diabetes in the diabetes control and complications trial. A randomized, controlled trial. Ann Intern Med. 1998; 128: 517-523.

14. Rowley MJ, Mackay IR, Chen $\mathrm{QY}$, et al. Antibodies to glutamic acid decarboxylase discriminate major types of diabetes mellitus. Diabetes. 1992; 41: 548-551.

15. Palmer JP. What is the best way to predict IDDM? Lancet. 1994; 343: 1377-1378.

16. Falorni A, Ackefors $M$, Carlberg $C$, et al. Diagnostic sensitivity of immunodominant epitopes of glutamic acid decarboxylase (GAD65) autoantibodies in childhood IDDM. Diabetologia. 1996; 39: 1091-1098.

17. Kobayashi T, Tamemoto K, Nakanishi K, et al. Immunogenetic and clinical characterization of slowly progressive IDDM. Diab Care. 1993; 16: 780-788.

18. Juneja R, Hirsch IB, Naik RG, et al. Islet cell antibodies and glutamic acid decarboxylase antibodies, but not the clinical phenotype, help to identify type 1(1/2) diabetes in patients presenting with type 2 diabetes. Metabolism. 2001; 50: betes in partie.

19. Torn C, Landin-Olsson M, Ostman J, et al. Glutamic acid decarboxylase antibodies (GADA) is the most important factor for prediction of insulin therapy within 3 years in young adult diabetic patients not classified as Type 1 diabetes on clinical grounds. in young adult diabetic patients not class
Diab Metab Res Rev. 2000; 16: 442-47.

20. Shiba T, Morino Y, Tagawa K, et al. Onset of diabetes with high titer anti-GAD antibody after IFN therapy for chronic hepatitis. Diab Res Clin Pract. 1995; 30: 237-241.

21. Fajans SS, Bell GI, Polonsky KS. Molecular mechanisms and clinical pathophysiology of maturity-onset diabetes of the young. N Engl J Med. 2001; 345: 971-980.

22. Yamagata $\mathrm{K}$, Furuta $\mathrm{H}, \mathrm{Oda} \mathrm{N}$, et al. Mutations in the hepatocyte nuclear factor-4 alpha gene in maturity-onset diabetes of the young (MODY1). Nature. 1996; 384: 458-460.

23. Froguel $P$, Vaxillaire $M$, Sun $F$, et al. Close linkage of glucokinase locus on chromosome $7 p$ to early-onset non-insulin-dependent diabetes mellitus. Nature. 1992; 356: 162-164.

24. Vionnet N, Stoffel M, Takeda J, et al. Nonsense mutation in the glucokinase gene causes early-onset non-insulin-dependent diabetes mellitus. Nature. 1992; 356: 721-722.

25. Vaxillaire $M$, Boccio $V$, Philipi $A$, et al. A gene for maturity onset diabetes of the young (MODY) maps to chromosome 12q. Nat Genet. 1995; 9: 418-423 
26. Yamagata K, Oda N, Kalsaki PJ, et al. Mutations in the hepatocyte nuclear factor-1alpha gene in maturity-onset diabetes of the young (MODY3). Nature. 1996; 384: 455-457.

27. Stoffers DA, Ferrer J, Clarke WL, et al. Early-onset type-II diabetes mellitus (MODY4) linked to IPF1. Nat Genet. 1997; 17: 138-141.

28. Horikawa $Y$, Iwasaki N, Hara M, et al Mutation in hepatocyte nuclear factor-1-beta gene (TCF2) associated with MODY. Nat Genet. 1997; 17: 384-385.

29. Malecki MT, Jhala US, Antonellis A, et al. Mutations in NEUROD1 are associated with the development of type 2 diabetes mellitus. Nat Genet. 1999; 23: 323-328.

30. Velho G, Froguel P, Clement $K$, et al. Primary pancreatic beta-cell secretory defect caused by mutations in glucokinase gene in kindreds of maturity onset diabetes of the young. Lancet. 1992; 340: 444-448.

31. Stride A, Vaxillaire $M$, Tuomi T, et al. The genetic abnormality in the beta cell determines the response to an oral glucose load. Diabetologia. 2002; 45: 427-435.

32. Menzel R, Kaisaki PJ, Rjasanowski I, et al. A low renal threshold for glucose in diabetic patients with a mutation in the hepatocyte nuclear factor-1 alpha (HNF-1alpha) gene. Diab Med. 1998; 15: 816-820.

33. Malecki MT, Skupien J, Gorczynska-Kosiorz S, et al. Renal malformations may be linked to mutations in the hepatocyte nuclear factor-1 (MODY3) gene. Diab Care 2005; 28: 2774-2776

34. Reznik $Y$, Dao $T$, Coutant $R$, et al. Hepatocyte nuclear factor-1 alpha gene inactivation: cosegregation between liver adenomatosis and diabetes phenotypes in two maturity-onset diabetes of the young (MODY)3 families. J Clin Endocrinol Metab. 2004; 89: 1476-1480.

35. Pearson ER, Starkey BJ, Powell RJ, et al. Genetic cause of hyperglycaemia and response to treatment in diabetes. Lancet. 2003; 362: 1275-1281.

36. Lindner TH, Njolstad PR, Horikawa Y, et al. A novel syndrome of diabetes mellitus, renal dysfunction and genital malformation associated with a partial deletion of the pseudo-POU domain of hepatocyte nuclear factor-1beta. Hum Mol Genet. 1999; 8: 2001-2008.

37. van den Ouweland JMW, Lemkes HHPJ, Ruitenbeek W, et al. Mutation in mito chondrial tRNA(leu-UUR) gene in a large pedigree with maternally transmitted type II diabetes mellitus and deafness. Nat Genet. 1992; 1: 368-371.

38. Guillausseau P-J, Massin P, Dubois-LaForgue D, et al. Maternally inherited diabetes and deafness: a multicenter study. Ann Intern Med. 2001; 134: 721-728.

39. Goto Y, Nonaka I, Horai S. A mutation in the tRNA(Leu)(UUR) gene associated with the MELAS subgroup of mitochondrial encephalomyopathies. Nature. 1990; 348: 651-653.

40. Malecki MT, Skupien J, Klupa T, et al. Maternally inherited diabetes with deafness and obesity: body weight reduction response to treatment with insulin analogues. Rev Diabet Stud. 2006; 3: 205-207.

41. Massin P, Guillausseau PJ, Vialettes B, et al. Macular pattern dystrophy associated with a mutation of mitochondrial DNA. Am J Ophthalmol. 1995; 120: 247-248.

42. Donohue WL, Uchida I. Leprechaunism: an euphemism for a rare familial disorder. J Pediatr. 1954; 45: 505-519.

43. Rabson SM, Mendenhall EN. Familial hypertrophy of pineal body, hyperplasia of adrenal cortex and diabetes mellitus; report of 3 cases. Am J Clin Pathol. 1956; 26: 283-290.

44. Kahn CR, Flier JS, Bar RS, et al. The syndromes of insulin resistance and acanthosis nigricans. Insulin-receptor disorders in man. N Engl J Med. 1976; 294: 739-745.

45. Cao H, Hegele RA. Nuclear lamin A/C R4820 mutation in Canadian kindreds with Dunnigan-type familial partial lipodystrophy. Hum Mol Genet. 2000; 9: 109-112.

46. Barroso I, Gurnell M, Crowley VEF, et al. Dominant negative mutations in human PPAR-gamma associated with severe insulin resistance, diabetes mellitus and hypertension. Nature. 1999; 402: 880-883.

47. Savage DB, Tan GD, Acerini CL, et al. Human metabolic syndrome resulting from dominant-negative mutations in the nuclear receptor peroxisome proliferator-activated receptor-gamma. Diabetes. 2003; 52: 910-917.

48. Gloyn AL, Pearson ER, Antcliff JF, et al. Activating mutations in the gene encoding the ATP-sensitive potassium-channel subunit Kir6.2 and permanent neonatal diabetes. N Engl J Med. 2004; 350: 1838-1849.

49. Babenko AP, Polak M, Cave $H$, et al. Activating mutations in the ABCC8 gene in neo natal diabetes mellitus. N Engl J Med. 2006; 355: 456-466.

50. Malecki MT, Skupien J, Klupa T, et al. Transfer to sulphonylurea therapy of adult subjects with permanent neonatal diabetes due to KCNJ11 activating mutations. Evidence for improvement in insulin sensitivity. Diab Care. 2007; 30: 147-149.

51. Mlynarski W, Tarasov Al, Gach A, et al. Sulfonylurea improves CNS function in a case of intermediate DEND syndrome caused by a mutation in KCNJ11. Nat Clin Pract Neurol. 2007; 3: 640-645. 